\title{
BODY TEMPERATURE AND ACTIVITY PATTERNS OF FREE-LIVING LAUGHING KOOKABURRAS: THE LARGEST KINGFISHER IS HETEROTHERMIC
}

\author{
Christine E. CoOper ${ }^{1,2,4}$, Gerhard Kortner ${ }^{2}$, Mark Brigham ${ }^{2,3}$, And Fritz Geiser ${ }^{2}$ \\ ${ }^{1}$ Environmental Biology, Curtin University of Technology, PO Box U1987, Perth, Western Australia, Australia \\ ${ }^{2}$ Centre for Behavioural and Physiological Ecology, Zoology, University of New England, \\ Armidale, N.S.W., Australia \\ ${ }^{3}$ Department of Biology, University of Regina, Regina, SK S4S 0A2, Canada
}

\begin{abstract}
We show that free-ranging Laughing Kookaburras (Dacelo novaeguineae), the largest kingfishers, are heterothermic. Their minimum recorded body temperature $\left(T_{b}\right)$ was $28.6^{\circ} \mathrm{C}$, and the maximum daily $T_{b}$ range was $9.1^{\circ} \mathrm{C}$, which makes kookaburras only the second coraciiform species and the only member of the Alcedinidae known to be heterothermic. The amplitude of nocturnal body temperature variation for wild, freeliving kookaburras during winter was substantially greater than the mean of $2.6^{\circ} \mathrm{C}$ measured previously for captive kookaburras. Calculated metabolic savings from nocturnal heterothermia were up to $5.6 \pm 0.9 \mathrm{~kJ}$ per night. There was little effect of ambient temperature on any of the calculated $\mathrm{T}_{\mathrm{b}}$-dependent variables for the kookaburras, although ambient temperature did influence the time that activity commenced for these diurnal birds. Kookaburras used endogenous metabolic heat production to rewarm from low $\mathrm{T}_{\mathrm{b}}$, rather than relying on passive rewarming. Rewarming rates $\left(0.05 \pm 0.01^{\circ} \mathrm{C} \mathrm{min}^{-1}\right)$ were consistent with those of other avian species. Captivity can have major effects on thermoregulation for birds, and therefore the importance of field studies of wild, free-living individuals is paramount for understanding the biology of avian temperature regulation.
\end{abstract}

Key words: Alcedinidae, Coraciiformes, heterothermia, temperature telemetry, torpor.

\section{Temperatura Corporal y Patrones de Actividad de Individuos Silvestres de Dacelo novaeguineae:} El Martín Pescador de Mayor Tamaño es Heterotérmico

Resumen. Mostramos que Dacelo novaeguineae, el martín pescador de mayor tamaño corporal, es heterotérmico. La temperatura corporal mínima $\left(\mathrm{T}_{\mathrm{b}}\right)$ registrada para esta especie fue de $28.6^{\circ} \mathrm{C}$ y el rango máximo de variación diaria fue de $9.1^{\circ} \mathrm{C}$, lo que hace a esta especie la segunda especie conocida como heterotérmica dentro de los coraciiformes y la única dentro de la familia Alcedinidae. La amplitud de la variación de la temperatura corporal nocturna para individuos silvestres de $D$. novaeguineae durante el invierno fue substancialmente mayor que la media de $2.6^{\circ} \mathrm{C}$ medida anteriormente en individuos de la misma especie en cautiverio. El ahorro metabólico resultante de la heterotermia nocturna fue de hasta $5.6 \pm 0.9 \mathrm{~kJ}$ por noche. Hubo poca influencia de la temperatura ambiental sobre cualquier variable dependiente de la $\mathrm{T}_{\mathrm{b}}$ de $D$. novaeguineae, aunque la temperatura ambiental influyó sobre el horario en que comenzó la actividad en estas aves diurnas. Los individuos de D. novaeguineae utilizaron la producción de calor metabólico endógeno para aumentar la $\mathrm{T}_{\mathrm{b}}$ baja, en vez de depender de un recalentamiento pasivo. Las tasas de recalentamiento $\left(0.05 \pm 0.01^{\circ} \mathrm{C} \mathrm{min}^{-1}\right)$ fueron consistentes con las reportadas para otras especies de aves. El cautiverio puede tener efectos importantes sobre la termorregulación en las aves, por lo que los estudios de campo con individuos silvestres son de extrema importancia para entender la biología de la regulación de la temperatura en las aves.

\section{INTRODUCTION}

The majority of birds are considered to be homeothermic endotherms, maintaining a high and stable body temperature $\left(\mathrm{T}_{\mathrm{b}}\right)$ by means of endogenous heat production. However, there is a considerable energetic cost of sustaining a high $T_{b}$, especially at low ambient temperature $\left(\mathrm{T}_{\mathrm{a}}\right)$, when $\mathrm{T}_{\mathrm{b}}-\mathrm{T}_{\mathrm{a}}$ differentials are large. One strategy by which this energetic demand may be reduced is heterothermy, during which rest-phase $T_{b}$ is reduced

Manuscript received 25 January 2007; accepted 30 September 2007

${ }^{4}$ E-mail: C.Cooper@curtin.edu.au and regulated below that of normothermic $\mathrm{T}_{\mathrm{b}}$, resulting in an increased nycthemeral $\mathrm{T}_{\mathrm{b}}$ rhythm (McKechnie and Lovegrove 2002). Heterothermic responses include hibernation and daily torpor, which are distinct from obligate hypothermia, which usually results from an inability to maintain physiological thermoregulation (McKechnie and Lovegrove 2002, Schleucher and Prinzinger 2006).

Heterothermia occurs more commonly in mammals than birds (Geiser et al. 2006). Worldwide, only 29 of 138 avian families within 11 of 30 orders are known to contain species that are heterothermic (McKechnie and Lovegrove 2002). Heterothermia appears to be more common in small species that inhabit regions with harsh or unpredictable climates and those

The Condor, Vol. 110, Issue 1, pages 110-115. ISSN 0010-5422, electronic ISSN 1938-5422. (c) 2008 by The Cooper Ornithological Society. All rights reserved. Please direct all requests for permission to photocopy or reproduce article content through the University of California Press's Rights and Permissions website, http://www.ucpressjournals.com/reprintInfo.asp. DOI: 10.1525/cond.2008.110.1.110. 
with diets that are temporally and spatially patchy (Hiebert 1993, McKechnie and Lovegrove 2002). Heterothermia has been studied in few bird species, particularly under free-living conditions. Quantitative data on heterothermy in free-living birds have been obtained for only a few species of caprimulgiforms (Brigham et al. 2000, 2006, Körtner et al. 2000, 2001), the White-backed Mousebird (Colius colius; McKechnie et al. 2004), and a passerine (Dolby et al. 2004). Several studies suggest that captivity substantially influences the use, depth and duration of facultative hypothermia in many birds and mammals (Geiser et al. 2000, Geiser and Ferguson 2001, Körtner et al. 2001, Dolby et al. 2004). For many species, captive individuals have reduced amplitude in $\mathrm{T}_{\mathrm{b}}$ oscillation compared to their wild, free-living counterparts. This may be due to a ready supply of food but may also be a consequence of not fully adjusting to captive conditions (Körtner et al. 2001).

Laughing Kookaburras (Dacelo novaeguineae) are the largest (360 g) members of the kingfisher family (order Coraciiformes, family Alcedinidae). Kookaburras are diurnally active birds that inhabit woodland and open forest throughout eastern Australia. They have also been introduced to Western Australia and Tasmania, where they are well established. Unlike other Australian kingfishers, family groups of kookaburras are sedentary and territorial year-round. They feed mostly on invertebrates, as well as small reptiles, birds, and mammals (Schodde and Tideman 1997).

In captivity, kookaburras exhibit low-amplitude, daily $\mathrm{T}_{\mathrm{b}}$ oscillation, with $\mathrm{T}_{\mathrm{b}}$ varying from $37.2^{\circ}$ to $39.7^{\circ} \mathrm{C}$ (Buttemer et al. 2003). However, year-round territory maintenance and a seasonally variable diet presumably place free-living kookaburras under energetic stress during winter in cold climates. The purpose of our study was to measure nocturnal $T_{b}$ and activity patterns of free-living kookaburras during winter to determine whether their thermoregulatory patterns differed from those of captive animals.

\section{METHODS}

Temperature-sensitive radio-transmitters were used to measure $\mathrm{T}_{\mathrm{b}}$ for five wild, free-living kookaburras near Armidale, New South Wales $\left(30^{\circ} 30^{\prime} \mathrm{S}, 151^{\circ} 39^{\prime} \mathrm{W}\right)$. Kookaburras were captured in mist nets or a raptor trap and assigned identification numbers. The $T_{b}$ of three kookaburras was monitored during July, August, and early September in 2003 (A03 for 34 nights, B03 for 49 nights, and $\mathrm{C} 03$ for 64 nights), and two kookaburras were monitored during June and July in 2004 (A04 for 12 nights and B04 for 19 nights).

Transmitters (Sirtrack Wildlife Tracking Solutions, Havelock North, New Zealand; $\sim 3.5 \mathrm{~g}$ ) were coated with a biologically inert wax (paraffin-Elvax, Minimitter Company, Inc., Sunriver, Oregon) and calibrated in a water bath at $\mathrm{T}_{\mathrm{a}}$ from $15^{\circ}$ to $50^{\circ} \mathrm{C}$ in $5^{\circ}$ increments. The temperature in the water bath was measured to $\pm 0.1^{\circ} \mathrm{C}$ with a thermometer traceable to a national standard. Temperature transmitters were then implanted into the abdominal cavities of the kokaburras under general anesthesia (oxygen-isoflurane). Kookaburras were returned to their sites of capture several hours after recovery from anesthesia. Measurement of $\mathrm{T}_{b}$ commenced two weeks after surgery to reduce any possible effects of capture, surgery, or anesthesia on $\mathrm{T}_{\mathrm{b}}$ regulation.

Remote logger-receiver systems were used to monitor $T_{b}$ nightly (Körtner and Geiser 1998) by recording transmitter pulse-intervals every 10 minutes. Ambient air temperature $\left(T_{a}\right)$ $1 \mathrm{~m}$ above ground level was recorded $\left( \pm 1^{\circ} \mathrm{C}\right)$ simultaneously via a temperature sensor connected to each data logger. Kookaburras were tracked to roost sites at dusk and logging systems set up within signal range and left running overnight. If a kookaburra returned to the same roost site for consecutive nights, the logging system was left running continuously for up to a week before downloading the data. Monitoring continued until transmitter signals could no longer be located. There was no evidence of a systematic change in $\mathrm{T}_{\mathrm{b}}$ data throughout the study; we thus assumed that transmitter calibration did not drift during the period of data collection.

We analyzed the data using a custom-written analysis program in Visual Basic 6.0 (Microsoft Corporation, Redmond, Washington), where the pulse intervals were converted to temperature $\left({ }^{\circ} \mathrm{C}\right)$ using the calibration curve for each transmitter. Temperature variables calculated (Fig. 1) were: minimum $T_{b}\left(T_{b \text { min }}\right)$, mean nocturnal $T_{b}\left(T_{b}\right.$ night $), T_{b}$ when arriving at the roost $\left(T_{b \text { arrival }}\right)$, and $T_{b}$ when leaving the roost $\left(T_{b}\right.$ active $)$, along with the associated $T_{a}$ and time of day. On nights when kookaburras changed roost sites, $\mathrm{T}_{\mathrm{b} \text { arrive }}$ could not be determined, as the $T_{b}$ recording commenced only after moving the

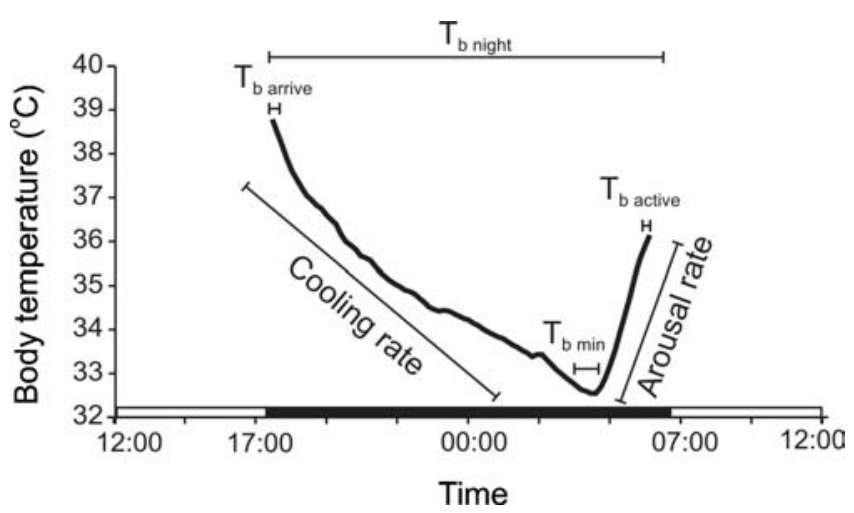

FIGURE 1. Body temperature of a Laughing Kookaburra (Dacelo novaeguineae) during its nocturnal rest phase. Time between sunset and sunrise is indicated by a thick dark bar along the $x$-axis. Thin bars indicate the calculation of various temperature variables; $\mathrm{T}_{\mathrm{b} \text { night }}=$ mean nocturnal body temperature, $\mathrm{T}_{\mathrm{b} \min }=$ minimum body temperature, $\mathrm{T}_{\mathrm{b} \text { arrive }}=$ body temperature when arriving at the roost site, $T_{\text {bactive }}=$ body temperature when leaving the roost site. Cooling and arousal rates were calculated as the slope of the regression of body temperature on time during cooling and arousal. 
logger to the new roost site. The range in $T_{b}$ was calculated by subtracting $T_{b}$ min from $T_{b \text { arrival }}$, as $T_{b \text { arrival was always the }}$ highest $T_{b}$ recorded at the roost. Unless stated otherwise, all $\mathrm{T}_{\mathrm{b}}$ characteristics refer to mean $\mathrm{T}_{\mathrm{b}}$ for at least 20 minutes (i.e., $\geq 3$ readings). Cooling and arousal rates were calculated from the slopes of the regressions of $\mathrm{T}_{\mathrm{b}}$ on time during periods of cooling after arriving at the roost and arousal before leaving the roost, respectively. We estimated energy savings resulting from heterothermy from metabolic rates $\left(\mathrm{VO}_{2 \text { calc }}\right)$ calculated using the equation $\Delta \mathrm{T}_{\mathrm{b}}=20.1 \times\left[\mathrm{VO}_{2 \text { calc }}-\mathrm{C} \times\right.$ $\left.\left(\mathrm{T}_{\mathrm{b}}-\mathrm{T}_{\mathrm{a}}\right)\right] /(m \times \mathrm{SH})$ after Withers et al. (1990) and Cooper and Withers (2004); $\Delta \mathrm{T}_{\mathrm{b}}$ is the change in $\mathrm{T}_{\mathrm{b}}\left({ }^{\circ} \mathrm{C} \mathrm{min}^{-1}\right.$; calculated from a 50 minute running average), $\mathrm{C}$ is thermal conductance $\left(0.139 \mathrm{ml} \mathrm{O}_{2} \mathrm{~min}^{-1}{ }^{\circ} \mathrm{C}_{;}^{-1}\right.$ Buttemer et al. 2003), $m$ is body mass (g, when captured), $\mathrm{SH}$ is the specific heat of tissues $(3.47 \mathrm{~J}$ $\mathrm{g}^{-1 \circ} \mathrm{C}^{-1}$ ), and $1 \mathrm{ml} \mathrm{O}_{2}$ is assumed to be equivalent to $20.1 \mathrm{~J}$. We assumed that kookaburras did not exhibit metabolic inhibition at the onset of the $\mathrm{T}_{\mathrm{b}}$ reduction. We compared $\mathrm{VO}_{2 \text { calc }}$ for actual $\mathrm{T}_{\mathrm{b}}$ to $\mathrm{VO}_{2 \text { calc }}$ for kookaburras maintaining a constant normothermic resting $\mathrm{T}_{\mathrm{b}}$ of $37.2^{\circ} \mathrm{C}$ (Buttemer et al. 2003). Energy savings were calculated for each kookaburra for the night they attained their lowest mean nightly $T_{b}$.

\section{STATISTICAL ANALYSIS}

All statistical analyses were conducted using statistiXL 1.6 (statistiXL, Nedlands, Australia). Temperature values are presented as means $\pm \mathrm{SE}$ for each individual, unless stated otherwise. Relationships between $T_{b}$ and $T_{a}$ were determined by least squares regression, and data for individual kookaburras were compared using ANOVA. Mean values for time of day were calculated using circular descriptive statistics, with time values presented as mean $\pm 95 \%$ confidence limits. Differences between $\mathrm{VO}_{2 \text { calc }}$ for kookaburras with actual $\mathrm{T}_{\mathrm{b}}$ and normothermic $\mathrm{T}_{\mathrm{b}}$ were assessed using a paired $t$-test. Significance was determined at $\alpha \leq 0.05$.

\section{RESULTS}

The mean body mass of the kookaburras we captured was 348 $\pm 16 \mathrm{~g}$ (range: $311-386 \mathrm{~g}$ ). Sex of the birds could not be determined. Individuals differed with respect to when they initiated roosting $\left(F_{4,155}=6.3, P<0.001\right)$. Initial roosting time of individual kookaburras varied from 17:05 $\pm 1 \mathrm{hr} 36 \mathrm{~min}$ to 18:11 \pm 9 min and ranged from $4.7 \pm 10.2$ min to $43.8 \pm 4.8 \mathrm{~min}$ after sunset. Roost arrival time was significantly affected by $\mathrm{T}_{\mathrm{a}}$ for only one individual (B04: $F_{1,11}=6.7, P=0.02, R^{2}=0.38$ ). Mean $\mathrm{T}_{\mathrm{b}}$ when roosting commenced (i.e., $\mathrm{T}_{\mathrm{b} \text { arrive }}$ ) ranged from $39.1 \pm 0.5^{\circ} \mathrm{C}$ to $39.9 \pm 0.2^{\circ} \mathrm{C}$, with corresponding mean $\mathrm{T}_{\mathrm{a}}$ of $6.2 \pm 0.9^{\circ} \mathrm{C}$ and $8.4 \pm 0.4^{\circ} \mathrm{C}$, respectively.

There was no significant difference for $\mathrm{T}_{\mathrm{b} \text { arrive among }}$ birds, although $\mathrm{T}_{\mathrm{a}}$ arrive did differ $\left(F_{4,165}=2.5, P=0.04\right)$. Only two individuals showed a significant positive relation-

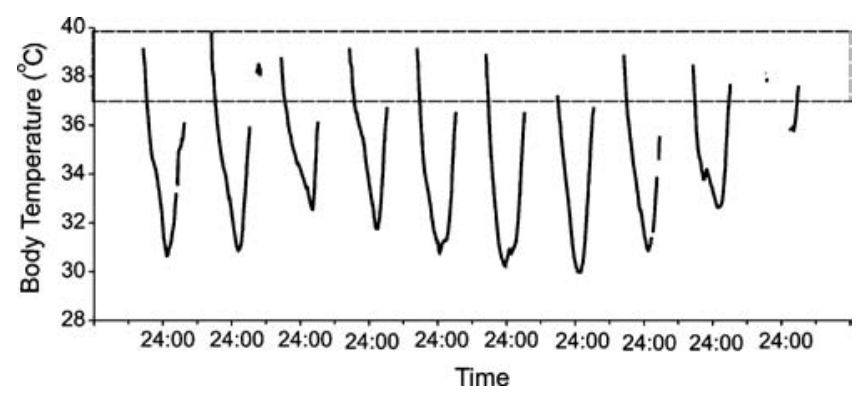

FIGURE 2. Nightly body temperature oscillation for a wild, freeliving Laughing Kookaburra (Dacelo novaeguineae). Breaks in the data occur when the bird was out of transmitter range. The region within the dashed border represents the body temperature variation of captive kookaburras (Buttemer et al. 2003).

ship between $\mathrm{T}_{\mathrm{a}}$ and $\mathrm{T}_{\mathrm{b} \text { arrive }}\left(\mathrm{C} 03: F_{1,62}=18.2, R^{2}=0.23\right.$, $P<0.001$; B04: $\left.F_{1,12}=18.3, R^{2}=0.60, P=0.001\right)$. Mean nighttime $\mathrm{T}_{\mathrm{b}}$ ranged from $34.8 \pm 0.4^{\circ} \mathrm{C}\left(\mathrm{A} 03: \mathrm{T}_{\mathrm{a}}=\right.$ $\left.2.2 \pm 1.1^{\circ} \mathrm{C}\right)$ to $37.6 \pm 4.8^{\circ} \mathrm{C}\left(\mathrm{B} 04: \mathrm{T}_{\mathrm{a}}=4.0 \pm 0.6^{\circ} \mathrm{C}\right)$. The relationship between $\mathrm{T}_{\mathrm{a} \text { night }}$ and $\mathrm{T}_{\mathrm{b} \text { night }}$, although weak, was significant for two kookaburras (B03: $F_{1,46}=6.2, P=$ 0.02, $\left.R^{2}=0.12 ; \mathrm{C} 03: F_{1,60}=21.8, P<0.001, R^{2}=0.27\right)$. All kookaburras exhibited nightly variation in $\mathrm{T}_{\mathrm{b}}$, with the mean difference between $\mathrm{T}_{\mathrm{b} \text { arrive }}$ and $\mathrm{T}_{\mathrm{b} \text { min }}$ ranging from $3.6 \pm$ $0.3^{\circ} \mathrm{C}$ to $6.8 \pm 0.3^{\circ} \mathrm{C}$ (Fig. 2). The smallest variation for a single overnight measurement was $0.3^{\circ} \mathrm{C}$, and the largest was $9.1^{\circ} \mathrm{C}$. Mean $\mathrm{T}_{\mathrm{b} \text { min }}$ occurred between 00:50 $\pm 40 \mathrm{~min}$ and 02:02 \pm $21 \mathrm{~min}$. Mean $\mathrm{T}_{\mathrm{b} \text { min }}$ ranged from $32.5 \pm 0.5^{\circ} \mathrm{C}$ to $36.0 \pm 0.3^{\circ} \mathrm{C}$; the lowest individual $\mathrm{T}_{\mathrm{b}}$ recorded was $28.6^{\circ} \mathrm{C}$ (A04). There was a significant, albeit weak relationship between $\mathrm{T}_{\mathrm{b} \text { min }}$ and $\mathrm{T}_{\mathrm{a}}$ for two kookaburras (B03: $F_{1,46}=6.3, P=0.01, R^{2}=$ 0.12 ; $03: F_{1,62}=12.9, P=0.001, R^{2}=0.17$ ).

The mean minimal nocturnal $\mathrm{VO}_{2 \text { calc }}$ for all five kookaburras (for the night when $\mathrm{T}_{\mathrm{b} \text { min }}$ was lowest for each bird) was $287 \pm 11 \mathrm{ml} \mathrm{O}_{2} \mathrm{~h}^{-1}$ for an average resting period of $12.2 \pm 1.1 \mathrm{hr}$. Mean nocturnal $\mathrm{VO}_{2 \text { calc }}$ for kookaburras, if they had maintained a normothermic resting $\mathrm{T}_{\mathrm{b}}$ of $37.2^{\circ} \mathrm{C}$, was calculated to be $310 \pm 10 \mathrm{ml} \mathrm{O}_{2} \mathrm{~h}^{-1}$ - significantly higher than the $\mathrm{VO}_{2 \text { calc }}$ for the actual $\mathrm{T}_{\mathrm{b}}\left(t_{4}=8.1, P<0.001\right)$. The calculated mean savings resulting from nocturnal heterothermia was $280 \pm 46 \mathrm{ml} \mathrm{O}_{2}\left(5.6 \pm 0.9 \mathrm{~kJ}\right.$, assuming $1 \mathrm{ml} \mathrm{O}_{2}$ is equivalent to $20.1 \mathrm{~J}$ ) per night (i.e., 12.2 hours).

Kookaburras roosted for $11 \mathrm{hr} 18 \mathrm{~min} \pm 21 \mathrm{~min}$ to 13 hr $7 \mathrm{~min} \pm 11 \mathrm{~min}$ per night. Roosting duration was significantly influenced by $\mathrm{T}_{\mathrm{a} \text { night }}$ for only one kookaburra (C03: $\left.F_{1,55}=17.8, P=0.001, R^{2}=0.24\right)$. Activity commenced between 05:41 $\pm 25 \mathrm{~min}$ and 06:15 $\pm 29 \mathrm{~min}$, from 34.2 $\pm 0.1 \mathrm{~min}$ to $38.3 \pm 4.8 \mathrm{~min}$ before sunrise (Fig. 3). The time activity commenced did not differ among individuals (time: $F_{4,166}=1.0, P=0.43$; time after sunrise: $F_{4,162}=$ $0.7 P=0.60)$. Time of departure from the roost in relation to sunrise was positively associated with $T_{a}$ for four of the five 


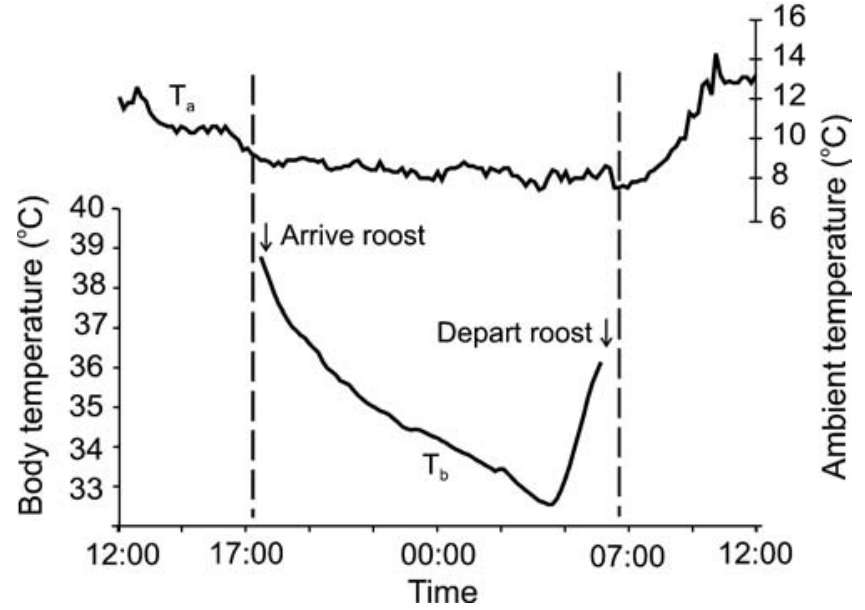

FIGURE 3. Body temperature of a Laughing Kookaburra (Dacelo novaeguineae), demonstrating rewarming prior to leaving the roost site. Rewarming occurs prior to sunrise and increasing ambient temperature and must therefore be due to endogenous heat production, not passive rewarming. The vertical dashed lines represent sunset and sunrise.

kookaburras $(P \leq 0.009)$. Mean $\mathrm{T}_{\mathrm{b} \text { active }}$ ranged from $37.1 \pm$ $0.4^{\circ} \mathrm{C}$ to $39.0 \pm 0.2^{\circ} \mathrm{C}$, at $\mathrm{T}_{\text {a active }}$ of $1.2 \pm 1.3^{\circ} \mathrm{C}$ and $2.3 \pm$ $0.7^{\circ} \mathrm{C}$, respectively. There was no difference for $\mathrm{T}_{\mathrm{a}}$ active among individual birds $\left(F_{4,163}=0.4, P=0.83\right)$; however, $\mathrm{T}_{\mathrm{b} \text { active }}$ did differ among individuals $\left(F_{4,169}=11.3, P<0.001\right)$. There was no relationship between $\mathrm{T}_{\mathrm{b}}$ active and $\mathrm{T}_{\mathrm{a}}$ active for any individuals. Mean cooling rates from $\mathrm{T}_{\mathrm{b} \text { arrive }}$ to $\mathrm{T}_{\mathrm{b} \text { min }}$ ranged from 0.9 $\pm 0.1^{\circ} \mathrm{Chr}^{-1}$ to $2.2 \pm 1.1^{\circ} \mathrm{C} \mathrm{hr}^{-1}$ and were always slower than arousal rates from $T_{b \text { min }}$ to $T_{b \text { active, }}$, which ranged from $1.7 \pm$ $0.1^{\circ} \mathrm{C} \mathrm{hr}^{-1}$ to $3.6 \pm 1.1^{\circ} \mathrm{C} \mathrm{hr}^{-1}$. There was no significant effect of $\mathrm{T}_{\mathrm{a}}$ on either cooling or arousal rates for any kookaburra.

\section{DISCUSSION}

The daily range in $T_{b}$ that we measured for free-living kookaburras shows unequivocally that kookaburras, the largest kingfishers, are heterothermic. Their extent of $T_{b}$ reduction meets most definitions of torpor (Reinertsen 1996, McKechnie and Lovegrove 2002, Schleucher and Prinzinger 2006). We demonstrate here that wild kookaburras exhibit greater amplitude of $T_{b}$ oscillation than measured previously for captive individuals (Buttemer et al. 2003).

Roosting times for kookaburras are comparable to those of other diurnal birds (Everding and Jones 2006), occurring during the dark phase of the day, for an average of about $12 \mathrm{hr}$ each night. For many birds, roost arrival and departure times are related to environmental factors such as day length, light intensity, cloud cover and $\mathrm{T}_{\mathrm{a}}$ (Swingland 1976, Brodsky and Weatherhead 1984, Reebs 1986, Everding and Jones 2006). During inclement weather, late departures and early arrivals, which result in longer periods of inactivity in the roost, presumably reduce thermoregulatory costs (Reebs 1986). We observed this for kookaburras, with roost departure times significantly influenced by $\mathrm{T}_{\mathrm{a}}$, and birds leaving the roost earlier before sunrise on warmer days. Therefore, even for larger birds such as kookaburras, there appears to be an energetic advantage to remaining in a roost longer when environmental conditions are unfavorable (Everding and Jones 2006). In addition, kookaburras prey mainly on invertebrates and small birds, reptiles and mammals, which are presumably less active during cold periods. Therefore, there may be little energetic advantage in becoming active early on cold mornings, so kookaburras remain in their roost later when $T_{a}$ is low.

Environmental factors generally have a stronger influence on the time at which birds leave a foraging site in the evening than on their arrival at the roost due to differences in foraging location and interactions en route to the roost site (Davis and Lussenhop 1970, Swingland 1976). This appears to also be the case for kookaburras. Arrival time at the roost in the evening was generally not related to $T_{a}$, and was much more variable between individual kookaburras than departure time in the morning.

Maximum nocturnal $\mathrm{T}_{\mathrm{b}}$ variation $\left(\mathrm{T}_{\mathrm{b} \text { range }}\right)$ for heterothermic birds shows a weak but statistically significant $\left(F_{1,56}=\right.$ 8.0, $\left.P=0.007, R^{2}=0.12\right)$ negative allometric relationship: $\mathrm{T}_{\mathrm{b} \text { range }}\left({ }^{\circ} \mathrm{C}\right)=-3.7( \pm 1.3) \log _{10} m(\mathrm{~g})+17.6( \pm 2.3)$; where $m=$ body mass (where $\mathrm{T}_{\mathrm{b} \text { range }}$ is the greatest recorded for a species; data from McKechnie and Lovegrove 2002). Kookaburras conform to this relationship, with their maximum nocturnal $\mathrm{T}_{\mathrm{b}}$ reduction of $9.1^{\circ} \mathrm{C}$ being $112 \%$ of that predicted (Fig. 4A). Associated with this is a weak but significant $\left(F_{1,82}=17.7, P<0.001, R^{2}=0.18\right)$ positive allometric relationship; $\mathrm{T}_{\mathrm{b} \min }\left({ }^{\circ} \mathrm{C}\right)=5.2( \pm 1.2) \log _{10} m+18.2$ $\left( \pm 1.9\right.$, where $T_{b}$ min is the lowest recorded for a species; data from McKechnie and Lovegrove 2002) for avian $T_{b}$ min. Kookaburras also conform to this relationship (Fig. 4B), with a $\mathrm{T}_{\mathrm{b} \text { min }}$ of $28.6^{\circ} \mathrm{C}$ that is $91 \%$ of that predicted from body mass. Birds with body mass $>80 \mathrm{~g}$ have not been reported to allow $\mathrm{T}_{\mathrm{b}}$ to fall below $20^{\circ} \mathrm{C}$ (data from McKechnie and Lovegrove 2002), suggesting that there is an upper mass limit for the occurrence of deep $\left(<20^{\circ} \mathrm{C}\right)$ torpor. Larger birds $(>80 \mathrm{~g})$, such as kookaburras and Tawny Frogmouths (Podargus strigoides; Körtner et al. 2001) are, however, capable of significant, although less substantial, reductions in $\mathrm{T}_{\mathrm{b}}$. Body mass appears to be an important factor determining the extent of nocturnal hypothermia for birds; although presumably other ecological, physiological and phylogenetic factors also influence avian $\mathrm{T}_{\mathrm{b} \text { min }}$ (Brigham et al. 2006).

Kookaburras are the second coraciiform species and the only member of the Alcedinidae known to employ heterothermy. The other heterothermic coraciiform species, the Puerto Rican tody (Todus mexicanus), weighs only $5-7 \mathrm{~g}$ and exhibits a $\mathrm{T}_{\mathrm{b}}$ range from $23.5^{\circ}-42.9^{\circ} \mathrm{C}$ (Merola-Zwartjes and 


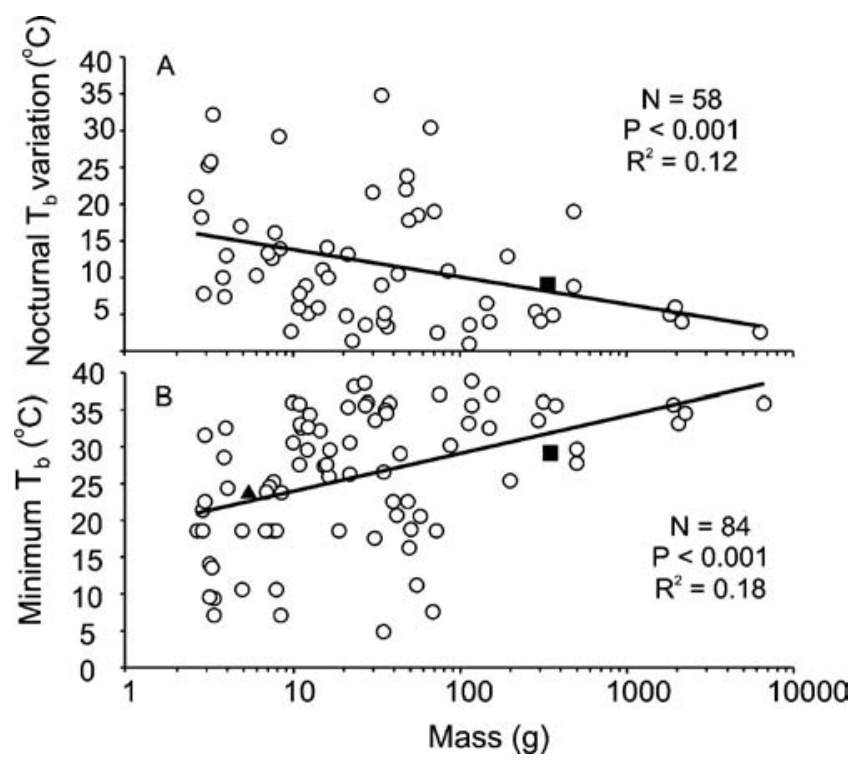

FIGURE 4. Allometric relationship for (A) avian maximum nocturnal body temperature $\left(\mathrm{T}_{\mathrm{b}}\right)$ oscillation and $(\mathrm{B})$ minimum body temperature. Data from McKechnie and Lovegrove (2002). The Laughing Kookaburra (Dacelo novaeguineae) is indicated with a dark square and the Puerto Rican Tody (Todus mexicanus; Merola-Zwartjes and Ligon 2000), with a dark triangle.

Ligon 2000). The minimum $T_{b}$ predicted for a tody by the allometric equation generated from McKecknie and Lovegrove's (2002) dataset is $22.2^{\circ} \mathrm{C}$. The tody's actual $\mathrm{T}_{\mathrm{b} \text { min }}$ of $23.5^{\circ} \mathrm{C}$ clearly conforms to the relationship and is $106 \%$ of that predicted (Fig. 4B).

Kookaburras had a $\mathrm{T}_{\mathrm{b} \text { arrive }}\left(39.1^{\circ}-39.9^{\circ} \mathrm{C}\right)$ that was comparable to the mean active-phase $\mathrm{T}_{\mathrm{b}}\left(39.7^{\circ} \mathrm{C}\right)$ of captive individuals (Buttemer et al. 2003). However, the overnight drop in $\mathrm{T}_{\mathrm{b}}$ for the wild, free-living kookaburras (up to $9.1^{\circ} \mathrm{C}$ with a mean reduction range of $3.6^{\circ}-6.8^{\circ} \mathrm{C}$ ) was substantially greater than the mean of $2.6^{\circ} \mathrm{C}$ measured for captive kookaburras (Buttemer et al. 2003; Fig. 2), despite similar $\mathrm{T}_{\mathrm{a}}$ variation in the two studies. Captivity appears to have a substantial effect on the occurrence, depth and duration of torpor in a number of birds and mammals (Geiser et al. 2000, Geiser and Ferguson 2001, Körtner et al. 2001, Dolby et al. 2004), although there is a paucity of $T_{b}$ data for wild endotherms. For example, wild Tawny Frogmouths exhibit nightly temperature fluctuations of up to $9^{\circ} \mathrm{C}$, while mean nocturnal $\mathrm{T}_{\mathrm{b}}$ fluctuation in captive individuals is only $0.4^{\circ} \mathrm{C}$ (Bech and Nicol 1999, Körtner et al. 2001). Presumably, captive birds are less energy limited than free-living birds and have a lower propensity to enter torpor. Captive birds may also not feel sufficiently secure to use heterothermy due to decreased responsiveness at low $T_{b}$. Comparison of captive and wild kookaburras indicates that kookaburras are capable of maintaining homeothermy, even at low $T_{a}$ (Buttemer et al. 2003) if they have access to sufficient energy. However, wild kookaburras clearly have the capacity to be heterothermic, which appears to be a facultative response that presumably helps them balance their energy budgets.

We found little effect of $T_{a}$ on any of the calculated $T_{b}$ variables for the kookaburras, with $<30 \%$ of the variation in $\mathrm{T}_{\mathrm{b}}$ attributed to $T_{a}$. Thus, we argue that $T_{a}$ has a relatively minor impact on $T_{b}$, presumably due to the comparatively large size of kookaburras and their nocturnal huddling behavior, which reduces thermal conductance. Presumably, $T_{a}$ has greater impact on $T_{b}$ patterns of smaller birds with a larger surface area to volume ratio, and thus greater thermal conductance (MerolaZwartjes and Ligon 2000).

Kookaburras used endogenous metabolic heat production to rewarm from low $T_{b}$ rather than relying on passive rewarming from increasing $T_{a}$ or solar radiation, as arousal to normothermic $T_{b}$ and commencement of activity occurred before sunrise and before $T_{a}$ began to rise (Fig 3 ). This confirms that the heterothermic response of these birds is an actively regulated, controlled process, and not simply an inability to meet thermoregulatory demands at low $T_{a}$. Nocturnal birds such as Tawny Frogmouths (Körtner et al. 2000, 2001) and Australian Owlet-Nightjars (Agotheles cristatus; Brigham et al. 2000) are also capable of using endogenous heat production to arouse from torpor at night, but may exploit solar radiation and increased $T_{a}$ to arouse from morning torpor, thus reducing the energetic costs of arousal. For kookaburras and other diurnal birds (Hiebert 1993), waiting to passively rewarm would require a substantial delay in activity and presumably reduce foraging success, especially for ectothermic prey that rely on basking to attain high activity levels. The overall mean warming rate during arousal of kookaburras was $75 \%$ of that predicted based on body mass by the equation $\log R=0.44-0.63 \mathrm{M}$, where $R=$ rewarming rate and $M=$ body mass (McKechnie and Wolf 2004; Fig. 5). However, kookaburras conform to this relationship, falling well within the $95 \%$ prediction limits (Cooper and Withers 2006).

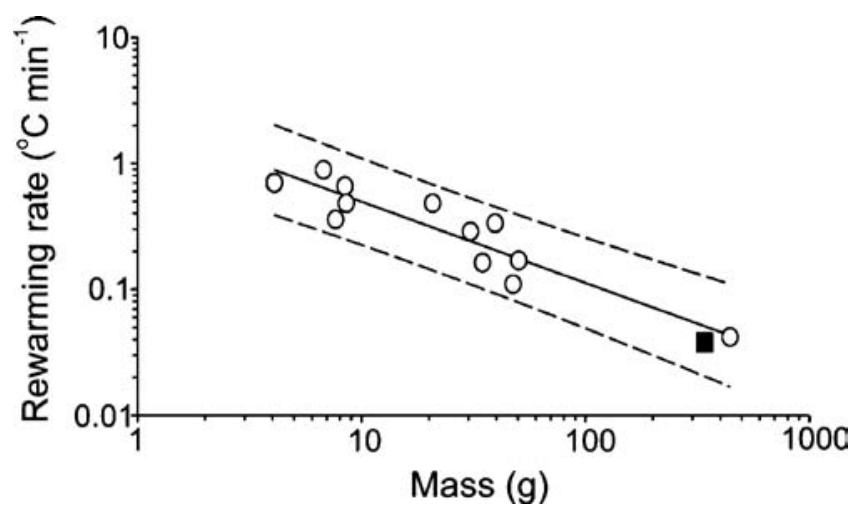

FIGURE 5. Relationship between log body mass and log rewarming rate for 13 bird species (white circles; data from McKechnie and Wolf 2004) and the Laughing Kookaburra (Dacelo novaeguineae; black square; this study). The solid line is the regression line, and the dashed lines, the $95 \%$ prediction limits for the regression. 
The costs of rewarming, along with low cooling rates, reduce the advantages of heterothermy for larger birds. However, our results suggest that even moderate drops in $T_{b}$ have an impact on a kookaburra's daily energy budget. Given the common occurrence of heterothermy, these energy savings must outweigh any potential costs, such as possible increased predation risk associated with low $\mathrm{T}_{\mathrm{b}}$ for kookaburras.

Captivity can have major effects on thermoregulation by birds, and therefore the importance of field studies of wild, free-living individuals is paramount for understanding the biology of avian temperature regulation. Our study shows that the largest member of the Alcedinidae, a family not previously known to have species capable of heterothermy, displays shallow nocturnal torpor. It would be interesting to investigate how others of the $\sim 100$ intermediately sized members of the family, especially small sedentary species, deal physiologically with inclement weather and limited food supply in the wild.

\section{ACKNOWLEDGMENTS}

We thank Rebecca Drury for her assistance with collection and preparation of the data, and two anonymous reviewers who provided constructive comments on the manuscript.

\section{LITERATURE CITED}

Brigham, R. M., G. KöRTNER, T. A. MAdDOCKS, AND F. Geiser. 2000. Seasonal use of torpor by free-ranging Australian Owlet-nightjars. Physiological and Biochemical Zoology 73:613-620.

Brigham, R. M., C. Woods, J. E. Lane, Q. E. Fletcher, and F. GEISER. 2006. Ecological correlates of torpor use among five caprimulgiform birds. Proceedings of the 23rd International Ornithological Congress, Acta Zoologica Sinica 52S:401-404.

BRodsky, L. N., AND P. J. WeATHERHEAD. 1984. Behavioural thermoregulation in wintering Black Ducks: roosting and resting. Canadian Journal of Zoology 62:1223-1226.

Buttemer, W. A., S. C. Nicol, And A. Sharman. 2003. Thermoenergetics of pre-moulting and moulting kookaburras (Dacelo novaeguineae): they're laughing. Journal of Comparative Physiology B 173:223-230.

CoOper C. E., AND P. C. Withers. 2004. Patterns of body temperature and torpor in the numbat Myrmecobius fasciatus (Marsupialia Myrmecobiidae). Journal of Thermal Biology 29:277-284.

COOPER C. E., AND P. C. Withers. 2006. Numbats and aardwolveshow low is low? A re-affirmation of the need for statistical rigour in evaluating regression predictions. Journal of Comparative Physiology B 176:223-629.

DAVIS G. J., AND J. F. LuSSENHOP. 1970. Roosting of Starlings (Sturnus vulgaris): a function of light and time. Animal Behaviour 18:362365.

Dolby A. S., J. G. Temple, L. E .Williams, E. K. Dilger, K. M. STECHLER, AND V. S. DAVIS. 2004. Facultative rest-phase hypothermia in free-ranging White-throated Sparrows. Condor 106:386390.
Everding S. E., AND D. N. JoNeS. 2006. Communal roosting in a suburban population of Torresian Crows (Corvus orru). Landscape and Urban Planning 74:21-33.

GeISER F., AND C. FERGUSON. 2001. Intraspecific differences in behaviour and physiology: effects of captive breeding on patterns of torpor in feathertail gliders. Journal of Comparative Physiology B 171:569-576.

Geiser F., J. C. Holloway, G. Körtner, T. A. Maddocks, C. Turbill, AND R. M. BRIGHAM. 2000. Do patterns of torpor differ between free-ranging and captive mammals and birds?, p. 95-101. In G. Heldmaier, and M. Klingenspor [EDS.], Life in the cold: Eleventh International Hibernation Symposium. Springer, Berlin, Germany.

Geiser F., G. Körtner, T. A. Maddocks, AND M. R. BrighaM. 2006. Torpor in Australian birds. Proceedings of the 23rd International Ornithological Congress, Acta Zoologica Sinica. 52S:405-408.

HieberT S. M. 1993. Seasonality of daily torpor in a migratory hummingbird, p. 25-32. In C. Carey, G. L. Florant, B. A. Wunder, and B. Horwitz [EDS.], Life in the cold: ecological, physiological and molecular mechanisms. Westview Press, Boulder, CO.

KöRTNER G., AND F. GEISER. 1998. Ecology of natural hibernation in the marsupial mountain pygmy-possum (Burramys parvus). Oecologia 113:170-178.

KöRTNER G., R. M. BRIGHAM, AND F. GeISER. 2000. Winter torpor in a large bird. Nature 407:318.

KöRTNER G., R. M. Brigham, AND F. GeISER. 2001. Torpor in freeranging Tawny Frogmouths (Podargus strigoides). Physiological and Biochemical Zoology 74:789-797.

McKechnie A. E., G. Körtner, And B. G. Lovegrove. 2004. Restphase thermoregulation in free-ranging White-backed Mousebirds. Condor 106:144-150.

McKechnie A. E., AND B. G. Lovegrove. 2002. Avian facultative hypothermic responses: a review. Condor 104:705-724.

McKeChnie A. E., AND B. O. Wolf. 2004. The energetics of the rewarming phase of avian torpor. Life in the cold: evolution, mechanisms, adaptation and application. Twelfth International Hibernation Symposium. Biological Papers of the University of Alaska 27:265-273.

Merola-Zwartjes M, AND J. D. Ligon. 2000. Ecological energetics of the Puerto Rican Tody: heterothermy, torpor and intra-island variation. Ecology 81:990-1003.

ReEBS S. G. 1986. Influence of temperature and other factors on the daily roosting times of Black-billed Magpies. Canadian Journal of Zoology 64:1614-1619.

REINERTSEN R. E. 1996. Physiological and ecological aspects of hypothermia, p 125-157. In C. Carey [ED.], Avian energetics and nutritional ecology. Chapman and Hall, New York.

SCHLeucher E., AND R. Prinzinger. 2006. Heterothermia and torpor in birds: highly specialized physiological ability or just deep "nocturnal hypothermia"?-The limitations of terminology. Proceedings of the 23rd International Ornithological Congress, Acta Zoologica Sinica. 52S:393-396.

Schodde R., And S. C. Tideman. 1997. Reader's Digest Complete Book of Australian Birds. Readers Digest, Sydney.

SWINGLAND I. R. 1976. The influence of light intensity on the roosting times of the Rook (Corvus frugilegus). Animal Behaviour 24:154158.

Withers P. C., K. C. Richardson, And R. D. Wooler. 1990. Metabolic physiology of euthermic and torpid honey possums Tarsipes rostratus. Australian Journal of Zoology 37:685-693. 